\title{
The shrinking political space of autonomist parties in an enlarged Europe of the Regions
}

\author{
Peter Lynch and Lieven De Winter
}

\section{Introduction}

For a period in the later 1980s and early 1990s, the idea of a Europe of the regions gained political prominence within the European Union. Though the idea of a Europe of the regions was an old one, it was given contemporary resonance in this period due to the European Union's structural fund reforms in 1988 which gave a new level of prominence to regional governments, with those regional governments also seeking some level of institutional representation within the EU. The outcome of this pressure was twofold: the creation of the Committee of the Regions as a consultative body within the EU (Loughlin 1996, Kennedy 1997), comprised of members of local and regional authorities, and the passage of the Treaty of European Union (Maastricht), which gave regional governments the constitutional ability to represent Member State interests within the Council of Ministers. For regional governments (as well as local governments), there was now a level of institutional recognition in the EU, with efforts to improve the regional level at subsequent EU treaty revisions at Amsterdam, Nice and then with the Convention on the Future of Europe. At this latter juncture, some regional governments had grouped together to establish the Congress of Local And Regional Authorities in Europe in 1999. This body sought to promote the interest of 'constitutional regions' in the EU - meaning those regions with strong powers and the ability to make legislation. This organisation 
also gave birth to REGLEG (Regions with legislative powers) and sought to promote greater representation for constitutional regions in the EU, a defined role for the regions in the EU constitution, a clear definition of powers and functions between the EU, national and subnational level, a strengthening of the Committee of the Regions and a direct right of appeal for regions to the European Court of Justice (Lynch 2004). ${ }^{1}$

Of course, these institutional developments are a small element of what would be a more ambitious view of a Europe of the Regions held by federalists and regionalists. The idea of a Europe of the Regions has been around for decades, though not necessarily in any coherent form. A Europe of the Regions has been seen as both a slogan (Loughlin 1996a: 150) and utopian vision for regionalists (Borras-Alomar et al, 1994: 2). The idea originated in the work of federalist writers such as Denis De Rougement (1966) and Guy Heraud (1974), who sought to promote European integration but also a role for regions in the political process. Heraud, for example, saw Europe as a federation of regions as opposed to a construction of artificial nation-states (Heraud, 1974). This idea had also been explored before this by committed regionalists such as the Bretons Maurice Duhamel (Dumhamel 1928) and Yann Fouere, with his idea of a Europe of a hundred flags (Fouere, 1968) as well as in Flanders by Maurits Van Haegendoren (1971). Such ideas provided some of the background to regionalist party thinking about European integration and these ideas, in addition to post-war consensus on the need for European co-operation to avoid military conflicts generated regionalist support for European unification (Lynch 1996). Besides a generally positive outlook towards Europe, regionalist parties found the Europe of the regions idea attractive because of hostility to centralised states but also to the perceived impact of European institutions in reducing the powers of the state upwards, whilst the regional level of government would reduce the powers of the state downwards: a regionalist version of the withering away of the nationstate.

The Europe of the regions idea has also been championed by regionalist parties, as an alternative to a state-centric European Union. Indeed, with some exceptions, most of the regionalist family is broadly supportive of European integration as a principle, though 
with qualifications on the exact nature of integration in relation to EU institutions, the policies pursued at the EU level and the various changes proposed to the EU treaties. Whilst individual regionalist parties have policies on EU policies, many of the parties are members of the European Free Alliance-Democratic Party of the Peoples of Europe, which operates as a transnational federation of most regionalists and acts as a collective voice in the EU and European Parliament. Thus, whilst regional governments have had representative organisations such as the Assembly of Regions, CALRE, Committee of the Regions, etc, regionalist parties have used the EFA-DPPE organisation to advance their cause in the European Parliament and Committee of the Regions. This is a much smaller focus than the COR, as most regions do not have regionalist parties, even though they may have regional governments. For much of its existence, the story of the EFA-DPPE has developed in two parts - firstly, successfully building up the organisation as a party family, secondly, struggling to establish a regionalist political group in the European Parliament. This latter enterprise has been problematic from the outset in 1979 but particularly so after the declining electoral fortunes of regionalist parties at the postenlargement 2004 European elections. This article will examine the 2004 performance in particular, in order to determine whether 2004 is indicative of an overall shrinkage in the political space for regionalist parties and the decline in saliency of the centre-periphery cleavage (Bartolini, 2005).

\section{The Development of the European Free Alliance and Regionalist Representation in the European Parliament}

The EFA-DPPE and Policy Integration Though the European Free Alliance started out with 6 founding members in 1981, it grew to 31 full members and 2 observer party members in 2007 (see table 1). However, expansion in the size of the party family has been incomplete. Indeed, the European Free Alliance can be considered as a weak but growing party family. Since its inception, the EFA has succeeded in organising the majority of active regionalist parties in Western Europe into its ranks. However, some of these parties are small and attract little electoral support. The EFA did manage to include the larger parties such as the SNP in the 1980s, the Lega Nord in the 1990s (until its 
expulsion in 1994) and the Partido Nacionalista Vasco as an EFA observer from 19992004. However, the fact that not all regionalist parties are within the EFA is significant, as it has rendered the EFA as an incomplete family representative (De Winter 2001). The most prominent examples are Convergencia $i$ Unio in Catalonia, which has never joined the European Free Alliance or associated with other regionalists in the European Parliament; the Lega Nord in Italy, which was an EFA member in the early 1990s before its expulsion from the organisation through its association with the AN in the 1994 centre-right coalition government of Berlusconi; the Süd-tiroler Volkspartei in Italy and the Svenska folkparteit in Finland. ${ }^{2}$ What is crucial about these parties is that they enjoy electoral representation in their member states, with a role in government and representation in the European Parliament. ${ }^{3}$ The latter fact deprived the EFA-DPPE of 8 MEPs in the European Parliament from 1999-2004 and then 6 MEPs from 2004 onwards (with 1 CDC, 1 PNV and 4 Lega Nord MEPs). Thus in the current period, the EFA-DPPE has only 5 MEPs from the regionalist family. In addition, there are a number of outliers within the regionalist party family who do not associate with the EFA or rather parties that the EFA would refuse to have as a member. The former Herri Batasuna from the Basque Country is one example, whilst the Vlaams Belang (formerly Vlaams Blok) is another. Whilst the autonomy goals of these two parties might fit with the European Free Alliance, their ideological attributes, policies and strategies do not. However, they add to the fragmented nature of the regionalist political family and the lack of fit between the EFA-DPPE and the universe of regionalist parties.

\section{Table 1. Membership of the European Free Alliance-Democratic Party of the} Peoples of Europe 2007

\section{Full Members (state)}

Alleanza Libera Emiliana (Italy)

Ålands Framtid (Sweden)

Bloque Nacionalista Galego (Spain)

\section{Observer Members (state)}

Liga Transilvania-Banat (Romania)

Magyar Foderalista Part (Slovakia) 


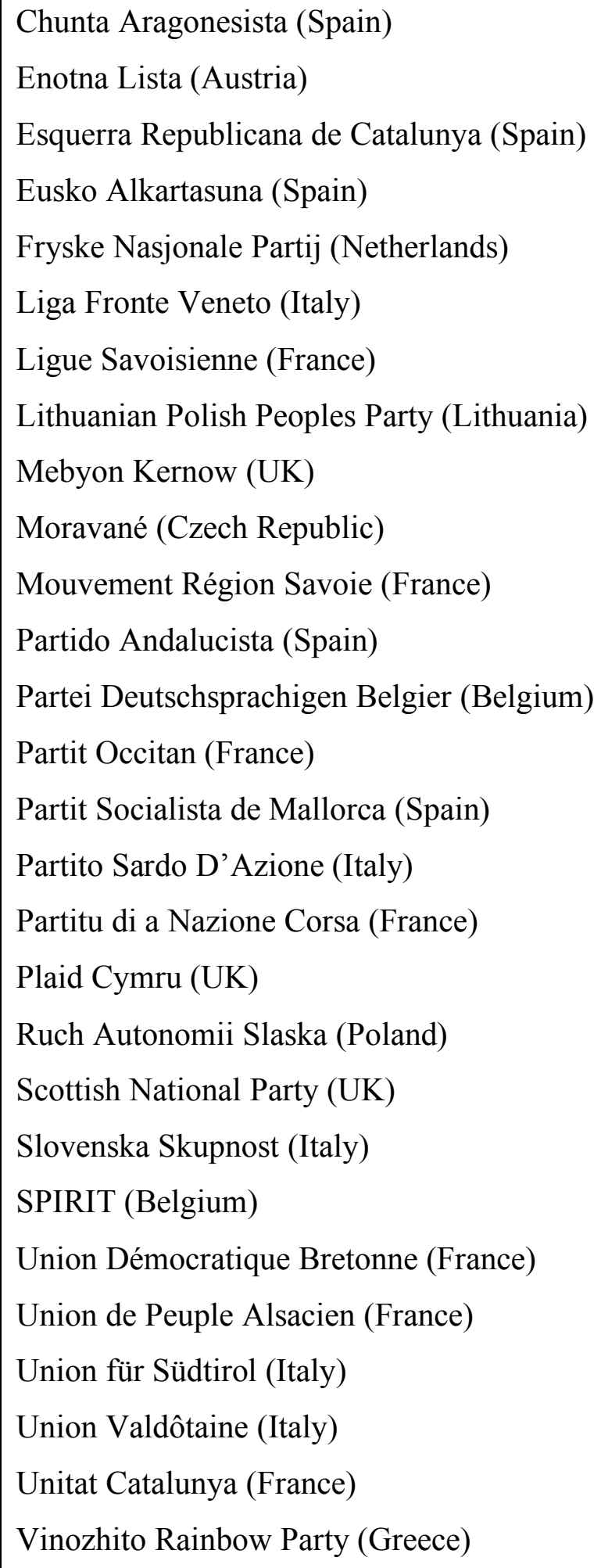


As the EFA-DPPE has grown, so has its common policy platform, though the depth of common policies is limited, even in the area of regional/national autonomy and the notion of a Europe of the regions. The regionalist family is not only ideologically diverse, but also features a variety of autonomy goals, even though united by the 'core business' of autonomy. This has effected the EFA's position on a Europe of the regions as well as on other EU policies. For example, it would be difficult for regionalists to adopt a common constitutional model for the EU either individually or as part of a common programme within the EFA-DPPE organisation. For example, individual regionalist parties support independence (SNP), full sovereignty (PNV), have ambiguous attitudes to independence and autonomy (Plaid Cymru), support federalism (Volksunie/SPIRIT, ${ }^{4}$ Partido Andalucista) and support regional autonomy. This diversity of opinion is reflected in the EFA-DPPE's stance on European integration and regional autonomy. In its 2005 statutes, the EFA-DPPE stated that it supported 'European unity and the creation of a European union of free peoples based on the principle of subsidiarity who believe in solidarity with each other and other peoples of the world' in addition to 'promoting the European integration based on the diversity of peoples, cultures, languages and regions. ${ }^{5}$ This position on the regionalists' 'core business' is obviously quite vague, reflecting the difficulties of generating an acceptable common position that reflects the variety of specific regionalist autonomy goals, not least when the parties' goals have evolved through both European integration and internal changes. ${ }^{6}$

Over time, the EFA began to develop a common platform that began as a set of common principles and then evolved into broader manifestos and policy positions. The EFA-DPPE parties are pro-European integration, seek defence/promotion of minority languages and support greater autonomy and representation for regions within EU institutions. In 2000, the EFA-DPPE sought to define itself as a proponent of 'progressive nationalism' meaning a party committed to:

- democracy and constitutionalism

- respect for human rights and minorities

- opposition to racism and xenophobia 
- civic and inclusive identities

- universal support for rights to self-determination of stateless nations

- pluralism over the constitutional form of self-determination

- peaceful political activities

- sustainable development and cultural and ecological diversity (EFA-DPPE 2000: 2)

The institutionalisation of the EFA-DPPE within the European Parliament and its participation in the Greens-EFA political group has led to a range of different policy positions and activities. The EFA-DPPE adopts policy positions in relation to sustainable development (Greens/EFA 2001); the main themes at European Council summits (Green/EFA 2002); a position on globalisation at the world parliamentary forum in Porto Alegre (Green/EFA 2002a); a policy towards the Convention on the Future of Europe (Green/EFA 2002b); and policy and participation at the United Nations summit on sustainable development in Johannesburg. These types of policy positions, in addition to policy stances adopted by the EFA at its general assemblies and the positions adopted by its MEPs mean that the EFA is now a much deeper organisation in terms of policy than it was at its inception. Not only have member parties adopted common policies, but policies in line with Green parties, which will become part of the platforms of new political parties joining the EFA-DPPE in future through enlargement: all examples of the impact of the Europeanisation of political parties that has been driven by European integration (De Winter and Gomez-Reino 2002).

European Parliament Representation The political parties associated with the European Free Alliance have struggled in relation to representation in the European Parliament. The EFA had some transnational predecessors in the 1940s (FUEN and the International Congress of European Nations and Regions) and the 1970s (the Bureau of Unrepresented European Nations), though most inter-regionalist contact occurred bilaterally between individual parties (Lynch 1996: 135-141). However, European integration in the specific form of direct elections to the European Parliament from 1979 onwards altered such practices considerably. Indeed, European elections drove the formation of the EFA, efforts at the construction of a regionalist political family, the 
establishment of a regionalist political group in the European Parliament as well as the development of cross-party co-operation between regionalists within EU member states to create electoral alliances for European elections (especially in France, Italy and Spain). However, whilst European elections have driven the construction of the EFA, the EFA has been least successful in relation to elections to the European Parliament, with very few of the EFA-DPPE parties succeeding in electing MEPs. For example, only 8 of the 31 existing EFA-DPPE members have elected MEPs since 1979. Moreover only 7 of those parties had MEPs in the 1999-2004 European Parliament, with one of them, from the Union Valdôtaine sitting with the ELDR not the other EFA-DPPE parties within the Green-EFA political group. The post-2004 position, despite enlargement, is not much better - with only 5 EFA MEPs.

The most striking characteristic about the impact of the regionalist political family in the European Parliament has been its failure to produce a regionalist political group. The EFA and DPPE emerged, but a strong and coherent regionalist political group has continued to elude the EFA parties. Instead, regionalist MEPs have participated in a range of political groups within the parliament. The EFA core around the Volksunie (now represented in the EFA by SPIRIT), was a member of five different groups since 1979 (see table 2). The Technical Co-ordination Group from 1979-84 was an ad hoc group of unattached MEPs, who sought to align to gain resources, committee memberships and staff: the prizes available to political groups. But, it only contained two regionalist MEPs, one from the Volksunie and one from the now extinct Rassemblement Wallon. Matters did not improve with Rainbow Group 1 from 1984-89, where 2 Volksunie MEPs and 1 Partito Sardo d'Azione MEP sat with the Greens, anti-European Danish party and some other small parties. However, from 1989-1994, the EFA was the predominant numerical contingent with Rainbow Group 2: the nearest thing to a regionalist political group. ${ }^{7}$ The EFA parties performed badly at the 1994 European elections and were left to form a small part of an ad hoc group with Énergie Radical from France and the Radical Party from Italy. Things improved in 1999 when the EFA-DPPE was reunited with the Greens, in a much more coherent political group, but there are still more regionalist MEPs outside this group than the ten EFA-DPPE MEPs in the parliament. The situation since 2004 is 
not dissimilar to this. The clear picture that emerges, though, is that the EFA's difficulties at group formation have become a permanent difficulty following each European election and that the EFA-DPPE has failed to organise all its potential parties within one political group. The EFA-DPPE may have become institutionalised as a party family, but the family has never become institutionalised in the European Parliament, in spite of over 25 years of organisational efforts, alliance-formation and bridge-building amongst regionalist and non-regionalist parties. And, of course, a changing constellation of states, regions and political parties through successive periods of EU enlargement.

Table 2. The EFA-DPPE and Political Groups in the European Parliament 1979-2009

\begin{tabular}{|lll|}
\hline Session & Group Name & Regionalist MEPs (group total) \\
$1979-84$ & Technical co-ordination group & $2(12)$ \\
$1984-89$ & Rainbow Group 1 & $3(20)$ \\
$1989-1994$ & Rainbow Group 2 & $8(15)$ \\
$1994-1999$ & European Radical Alliance & $4(19)$ \\
$1999-2004$ & Greens-European Free Alliance & $10(45)$ \\
$2004-2009$ & Greens-European Free Alliance & $5(42)$ \\
\hline
\end{tabular}

EU Enlargement The imminent prospect of EU enlargement in 2004 provoked efforts at EFA-enlargement: though this activity has been a constant one since the establishment of the European Free Alliance in 1981. However, given the political landscape in the East with relatively new, weak and unstable regionalist political parties, extending the EFA family has not been easy. The positive side of enlargement for the EFA was the large number of ethnic and linguistic minorities in the Eastern states though the negative side was the political complexion of some of these parties and the absence of regional governments in the acceding states. Whilst there are clear minority questions in states such as the Czech Republic, Poland and Slovakia, very few of these minorities have strong language or regionalist political parties: the Hungarian communities in Rumania 
and Slovakia stand out as the only substantial examples. Moreover, these is little of the 'bottom-up regionalism' found in Western Europe (Keating and Loughlin 1997), where regionalist parties have politicised the centre-periphery cleavage to the extent that central governments have established regional government (Keating and Hughes 2003). Regional structures have been on the agendas of Eastern European governments in recent years, with decentralisation linking up with the need to manage EU structural funds in the regions, but there are few similarities at this time with the Basque Country, Catalonia, Flanders or Scotland. This is not to discount future developments however, for two reasons. First, regionalism as a political force can be quite fluid and unpredictable, clearly indicated by emergence of new regionalism through the unexpected rise of the Lega Nord in Italy, the Vlaams Blok in Flanders as well as smaller parties in France and Spain. Regionalism is not purely a product of the 1960s and 1970s. Second, regionalism is not merely the practice of political parties. Regional governments also drive regionalist policies and agendas. Despite their ethnic and linguistic homogeneity and lack of regionalist parties, the German Länder have been active in setting the regional agenda domestically and across Europe to become assertive policy actors within the European Union (e.g the Committee of the Regions and regional access to the Council of Ministers). The development of regional governments in Eastern European states in the coming years may therefore generate a form of regionalism that boosts regional involvement in EU institutions and policies.

Whilst regionalist parties within the EFA-DPPE have been generally supportive of the last two decades of European deepening, they have faced a challenging political opportunity structure through the widening of the EU. Indeed, with the exception of Spanish accession in 1986, enlargement has brought little to the EFA-DPPE in the way of member parties, new allies and MEPs. Despite the fact that regionalists have not benefited from the enlargement of the EU to add Greece, Portugal, Austria, Finland and Sweden, followed by ten new states in 2004 and then Bulgaria and Rumania in 2007, the EFA-DPPE has grown, albeit through adding relatively small parties. However, it is arguable that the Eastern enlargement has had a negative impact on the EFA-DPPE, as it has markedly altered the balance of the EU away from states with strong regionalist 
parties and regional governments. Enlargement in 2004 added ten predominantly centralised states to the European Union as opposed to regionalised or federal states. ${ }^{8}$ Indeed, as this article will argue, whilst other Euro-parties benefited from enlargement at the European elections in 2004 and 2007 - with new states bringing large numbers of new MEPs - the EFA-DPPE struggled to maintain let alone expand its level of representation in the European Parliament. The nature of the expansion also made the prospect of a Europe of the regions even more remote. However, this situation is very much "problems as usual" for the EFA-DPPE. It has faced endemic problems in electing MEPs and constructing a political group from 1979 onwards: especially as EFA MEPs currently only represent $3 \mathrm{EU}$ member states. Participation in political groups with MEPs from other party families has been the norm for the EFA-DPPE.

The EFA itself sought to expand into the accession states and beyond. In the early 1990s, the Slovene minority party in Northeast Italy, Slovenska Skupnost and the Slovak independence party, Slovenska Narodna Strana joined the European Free Alliance. Similarly, the EFA and Rainbow Group became involved in the International Network of Centre Parties, to explore links with parties from Scandinavia (in preparation for Finland and Sweden joining the EU in 1995) as well as the Baltic states and East-central Europe. The EFA parties were involved in meetings in Poland and Estonia with centrist parties from Estonia, Latvia, Lithuania, Hungary and Poland, but the collapse of the Rainbow group in 1994 led to the abandonment of this project (Lynch 1996: 149). However, such efforts continued in the 1990s and into the new century. For example, representatives of the Hungarian minority came to Brussels to meet with the EFA in March 2001. An event quickly followed by the EFA visit to Slovakia in April 2001 to investigate the treatment of the Hungarian and Roma minorities in the accession state, and also explore the prospects for electoral co-operation and member parties. At the EFA general assembly in November 2001, four regional/minority parties joined the EFA as observers, with some subsequently becoming full members (see table 1). Further visits were made by the EFA to Poland in 2002 and 2003, with an EFA conference in Poland alongside the Silesian minority. The EFA also organised conferences in Lithuania in July 2003 and Romania in 
September 2003, to explore minority issues as well as the prospects for post-enlargement electoral co-operation and EFA membership.

One of the difficulties with the EFA expansion to the East is the quality, organisation and electoral presence of the various regionalist parties who have sought to become EFA members. For example, electoral data on the 4 parties from the accession states that have become members and observers of the EFA is extremely thin. Ruch Autonomii Slaska (established in 1990) from Poland did not feature prominently at the 2001 election to the Sejm, where it was part of the Civic Platform list, in contrast to Mniejszosc Niemiecka (MN - German Minority) which gained 47,230 votes (0.36\%) in 2001 and then 34,469 votes $(0.3 \%)$ in 2005 and 2 seats on each occasion and Niemiecka Mniejszosc Górnego Slaska (MGS - German Minority of Upper Silesia) which gained 8,024 votes in 2001 (0.06\%). Ruch Autonomii Slaska and the MGS agreed to establish an electoral coalition for the local and regional elections of 2002, but there is no data on its performance at this election. Where Ruch Autonomii Slaska did perform at the 2001 election was in the Senate contest, where its candidates gained an average of $17 \%$ in the three main Silesian constituencies (Gliwice, Katowice and Rybnik) where it gained a total of 157,277 votes. However, this level of support was completely obscured by the electoral performance of the main political parties in Poland.

The Magyar Föderalista Part also did not feature independently in recent elections in Slovakia in 2002, 2003 and 2006, but as part of the broader Strana mad arskej koalície Magyar Koalíció Pártja which achieved 321,069 votes (11.16\%) and 20 seats at the 2002 election to become the fourth largest party and had four Ministerial posts in the coalition government. In alliance with other parties, the MKP won control of 5 of the 8 Slovak regional councils at the 2003 followed by $11.7 \%$ and 20 seats at the 2006 general election. In the Czech Republic, there is no electoral record for Moravané, a current full EFA member, though the Moravska demokraticka strana (Moravian Democratic Party) gained 12,957 votes $(0.27 \%)$ in 2002 . Finally, the Liga Transilvania-Banat became involved with the EFA-DPPE before the 2007 Romanian accession, but is a party that had no presence in recent Romanian elections, in contrast to the DMR/RMDSZ - 
Democratic Union of Hungarians in Romania (Uniunea Democrata a Maghiarilor din Romania) which gained 736,863 votes $(6.8 \%)$ and 27 seats at the 2000 legislative elections and $6.2 \%$ and 22 seats in 2004. The only other EFA member from enlargement was the Polish Peoples Party in Lithuania for which there is no electoral data (though it has succeeded in electing an MEP and joining the Greens- EFA group in the European Parliament), in contrast to Electoral Action of Lithuanian Poles (Lietuvos lenku rinkimu akcija), which gained 28,641 list votes (1.95\%) and 40,376 constituency votes (2.75\%) and 2 seats out of 141 seats at the 2000 election and 2 seats and 3.8\% in 2004. European parliamentary electoral data on all of these parties will be considered below.

The EFA's limited success in recruiting regionalist parties through EU enlargement is not surprising, as it reflects the limited numbers of existing parties in the East and the absence of regional structures. The area is characterised by linguistic and national minorities, border issues, etc, but these have not played into the EFA's hands at this point. The EFA's difficulties in the East - in terms of recruiting parties and also prospective MEPs - are clearly illustrated in comparison to the traditional party families. For example, the Socialist Group in the European Parliament has 6 MEPs from Bulgaria, 9 MEPs from Hungary, 9 MEPs from Poland and 3 from Malta, whilst the European Peoples Party group has 15 MEPs from Poland, 9 from Romania, 8 from Slovakia and 13 from Hungary. In addition, many of the parties from the 2004 and 2007 accession states are large parties and also governing parties. Moreover, as indicated above, some of the parties which might be expected to associate with the EFA-DPPE such as the Magyar Koalíció Pártja in Slovakia are members of another political group - in this case the EPP. The MKP's two MEPs therefore sit with a non-regionalist party group, giving no aid at this stage to the prospects for expanding the MEP-contingent within the European Parliament to advance the prospects of a regionalist party group. Thus Eastern enlargement may have the effect of adding to the size of the regionalist contingent within the European Parliament which is not aligned with the European Free Alliance or a regionalist political group within the parliament. 
However, one of the defining characteristics of the EFA since its inception has been its involvement in party-building and alliance construction. The EFA staff in Brussels and the Volksunie MEPs in particular, were active in assisting small regionalist parties to develop their policies, organisations and electoral capacities. ${ }^{9}$ Indeed, in terms of administration, electoral expertise and organisation, the EFA structure operated as an external support system for regionalist parties in France and Italy. Similarly, the EFA assisted regionalist parties to construct and maintain electoral alliances for European elections in order to increase the chances of regionalist MEPs being elected: evident in France, Italy and Spain, with some successes over time. Thus, whilst the current electoral/organisational situation of regionalist parties in the accession states looks bleak, the EFA-DPPE organisation will seek to improve this situation through intervening to aid parties in terms of support, resources and expertise and help create electoral coalitions to help Eastern regionalists to surpass electoral thresholds at European, national and regional elections. However, even here, we are talking about very small numbers of MEPs being elected.

\section{The Highpoint of the EFA-DPPE}

The 1999-2004 parliament, can be seen as something of a high point for the EFA parties, during which they had their highest number of MEPs elected and formed a more substantial component of the Green-EFA political group. Though not a regionalist group, the alliance with the Greens was solid and involved a series of common policy initiatives. Moreover, the EFA helped establish a political group in the Committee of the Regions the European Alliance - to extend the family's EU institutional representation into the COR for the first time. However, even at its peak, the downside of this situation was that the EFA contingent only involved 3 member states - Belgium, Spain and the UK - and a small number of parties. Marginal changes to support for those parties with two MEPS (Plaid Cymru, SNP and SPIRIT) or reduced representation of member states in the European Parliament due to enlargement itself, would have the effect of reducing the number of the EFA MEPs significantly. Indeed that was exactly what happened in 2004. Plaid was reduced to one MEP, the Volksunie disappeared into successor parties like 
SPIRIT (De Winter 2006) which is an EFA-DPPE party that sits in the Socialist group whilst shifting electoral alliances and losses of electoral support in Spain saw the loss of the MEPs who represented the BNG, PNV and Partido Andalucista and only left the MEP shared by Eusko Alkartasuna/ERC. The 2004 election therefore had consequences for the EFA-DPPE parties within the European Parliament, with little prospect of their replacement by regionalist parties from the accession states as was explained above. If these problems weren't enough, the rules of the game for recognition and funding of Euro-parties and political groups changed with enlargement. Euro-parties will be required to contain at least 8 member parties from the 27 member states, with representatives elected at the European, national or regional level. Whilst political groups within the European Parliament will have to comprise MEPs representing at least $20 \%$ of the member states, with a minimum of 20 MEPs needed to form a group (European Parliament 2003).

Whilst regionalist parties have experienced a limited role within the European Parliament due to the electoral performance of party family members, European integration has generated other arenas for regionalist political mobilisation. Both the Committee of the Regions and the recognition of Constitutional Regions within the EU have produced new opportunities for regionalist parties (Lynch 2004). Within the Committee of the Regions, the EFA parties were initially marginalised but following the organisation of COR representatives into party groups they developed a more coherent role - though for one term of the COR only. Within the COR, EFA aligned with a group of independents from English local authorities plus Ireland's governing party, Fianna Fail, to establish the European Alliance as a party group from 1999-2004. The group had clear parallels with the organisation of regionalists in the European Parliament, with the need for a formal alliance with non-regionalists to establish political groups that would be recognised and funded by European institutions. The EFA parties were a minority within the European Alliance, but then so were Fianna Fail and the Independents. Clearly, without this group, each would be unattached members of the COR and lack committee places and political clout. The EFA members within the COR were not marginal figures within the sphere of multi-level governance. EFA members of the COR included: Paul Van Grembergen of 
SPIRIT, the Flemish Minister for Interior, Housing, Civil Service, Foreign Trade and Urban Policy; Keith Brown of the SNP, a local council leader; Juan José Ibarretxe of PNV, who was President of the Basque Country; Dino Viérin of the Union Valdotaine, who was President of the Autonomous Region of Val D'Aosta. ${ }^{10}$ Thus, four of the European Alliance's COR delegation of ten members came from the EFA parties. Amongst the alternate COR members, the EFA was represented by politicians from SPIRIT, Plaid Cymru, the PNV and the SNP. Similarly, though the European Alliance was a relatively loose grouping of regionalists and non-regionalists, it developed some programmatic coherence as necessitated by European institutional rules plus the need for group coherence within the COR. The European Alliance had eight main principles, which were closely aligned with long-standing EFA policy positions:

- Environmental and Sustainable development as defined in the Brundtland Report from the UN with the full implementation of the Kyoto Protocol.

- Peace, détente;

- Freedom and right of self-determination;

- Defence of all languages, cultures and local government;

- An open Europe of autonomous regions and nations;

- Openness and grass-roots democracy;

- Sound management of all European structures, in order to prevent fraud and waste.

- The defence of human rights (European Alliance 2004).

European Alliance members were committed to 'actively support and vote for an open Europe of regions and nations and the highest possible standards for environmental protection, workers' health, consumer protection, veterinary rules, social welfare and democratic principles. The members commit themselves to work together to obtain and defend such rights and equality of treatment. At the same time, they acknowledged the full political autonomy of the individual members and groupings.' (European Alliance 2004). Thus, similar to previous quasi-regionalist political groups, the European Alliance simultaneously adopted common positions and allowed members to act autonomously: another uneasy balancing act for the parties involved. However, this version of the 
European Alliance ran for only one term. From 2004, the organisation was reconstituted as the Union for Europe of the Nations-European Alliance group and the EFA-DPPE were parties left without a political group to join. Despite EFA-DPPE representation in the COR and the presence of EFA parties in regional parliaments and some governments, the regionalists found themselves institutionally marginalised within the Committee of the Regions.

\section{Regionalist Parties at the 2004 European Elections}

The 2004 elections constituted a disaster for the EFA in terms of parliamentary representation and electoral support. The number of MEPs dropped to only five $\mathrm{e}^{11}$, which formed a grouped with 37 Greens MEPs. The non-EFA autonomist MEPs nearly tripled the number of EFA MEPs. As we will see further on, this may have considerable consequences for keeping the party family's niche in the European political space, its organisational resources and generally for its chances of survival. But first let us examine the fortune of individual parties per country and region, encompassing both EFA and non-EFA parties.

Starting our regional overview from the North, the Swedish People Party lost 1.1\%, but with $5.7 \%$ of the national vote it still managed to keep its seat in the EP, in spite of the fact that number of Finnish MEPs was reduced by two at the 2004 European elections. In the UK, ${ }^{12}$ the SNP suffered a severe defeat: $19.7 \%$ of the Scottish vote, or $-7.5 \%$ compared to its unprecedented success at the 1999 Euro elections, where it nearly became the first Scottish party (27.2\%, or $1.5 \%$ less than Scottish Labour), and it also became the official opposition party at the first elections to the Scottish Parliament. It managed however to keep its two seats in the EP, in spite of the reduction of the number of Scottish MEPs from eight to seven. Since 1987 the SNP had not scored below 20\%, and as also the 2003 regional parliamentary elections the SNP suffered a severed drawback, the party leader Swinney decided to resign and was succeeded by his predecessor, Salmond, who had awarded his party several historical electoral victories (as he managed to do again at the Scottish elections of May 2007). Plaid Cymru suffered an even bigger 
blow (17.4\% of the Welsh vote, or $-12.2 \%$ ) and became Wales' third party, halving its representation to one MEP. Although the number of Welsh MEPs was reduced from five to four, this did not cause the loss of the second Plaid seat in the EP. Also here the bad score at the European Elections was preceded by a major defeat at the second elections of the Welsh Assembly (2003). Contrary to the SNP, the 2007 Welsh elections did not produce an impressive comeback $(21 \%$, or $+1.4 \%)$.

The success of the Belgian autonomist parties has become very difficult to measure. Since 1993, the Front Démocratique des Francophones has presented a common list with the francophone liberal party for all elections except for local ones. In Flanders, after the split of the Volksunie into an independist Nieuw-Vlaamse Alliantie and a post-nationalist SPIRIT both inheritors formed electoral cartels with the Flemish Christian Democrats and Socialists respectively. It therefore has become impossible to measure the weight of these autonomist parties in each cartel, although both cartel lists reaped considerable benefits from cooperation. Thus only the Vlaams Blok's ${ }^{13}$ performance can be measured, and once again it made a considerable leap forward since the last European elections (from $15.1 \%$ to $23.2 \%$ of the Flemish vote) (De Winter, Gomez-Reino and Bulens, 2006). Still this leap is less impressive than its score at the Flemish and Brussels elections that were held the same day as the European ones $(24.2 \%$ and more than a third of the votes cast for Flemish parties for the parliament of the bilingual Brussels Capital Region, 34.3\%). Finally the PDB (Partei Deutchsprachigen Belgier) did compete for the only seat reserved for the German-speaking minority, and obtained $9.3 \%$ or (-0.6\% compared to the 1999 elections). In France, due to the shift from a national constituency to eight interregional constituencies, regionalist parties have not put up specific lists but joined cartels or did not participate at all.

In Italy, the Lega Nord obtained 5\% measured at the national scale, a slight increase of $+0.5 \%$ in spite of the incapacitating health condition of its supreme leader, Umberto Bossi, and the fact that a dissident list Lega Lombarda won $0.5 \% .^{14}$ The Sud-tiroler Volkspartei obtained $46.7 \%$ of the South-Tirolean vote (56.\% at the 1999 European elections), while the Union Valdotaine also dropped from $45.9 \%$ to $37.5 \%$. In the other 
Italian regions, the party of the Slovenian minority Slovenska Skupnost was part of the Magherita cartel. The Partido Sardo d'Azione presented a common list with the "Lega Lombarda", the Union für Südtirol, the Liga Fronte Veneto, and Lega Pensionati in the constituency Sicily-Sardinia which obtained only 0.5\% (2.6\% in Sardinia in 1999).

Last but not least, there is the traditionally rich but complex case of Spain, due to its multitude of autonomist and regionalist parties, as well as shifting electoral coalition behaviour. In 2004, three main autonomist cartels were formed. The first one, GalEusCa - Pobles d'Europa, contained the predominant autonomist party of the three historical autonomies, the Catalan Convergencia I Unio, the Basque Partido Nacionalista Vasco and the Galician Bloque Nacionalista Galego. To this were added a few minor parties such as the Valencian Bloc Nationalista Valencià, Partit Socialista de Mallorca - Entesa Nacionalista of the Balearic Islands. A second cartel, Europa de los Pueblos, was formed between the main competitor parties to the ones above, the Catalan Esquerra Republicana de Catalunya, the Basque Eusko Alkartasuna, the Valencian Esquerra Republicana del Pais Valencià, the Andalusian Asamblea de Izquierdias - Partido Socialista de Andalucia, the Conjegu Nacionaliegu Cantabru of Cantabria, the Andecha Astur of Asturias, the Iniciativa Ciudadana de la Rioja, and the Chunta Aragonesista. Most of these parties are situated on the left of the political spectrum and are of the European Free Alliance. Finally, a third cartel, the Coalición Europea, comprised the Coalicion Canaria, the Unio Valenciana, the Unio Mallorquina, the Partito Aragones, the Convergencia de Democratas de Navarra and the Partido Andalucista (the latter is also an EFA member party)

Hence, a diachronic comparison of the performance of the autonomist-regionalist family at the European election in Spain is not clear-cut. If we compare the overall score of this family at the state-wide level (Spain constitutes a single constituency, hence the tendency to form cartels), we can notice a dramatic decline of the nationalist vote, from $13.97 \%$ to $8.92 \%$ in 2004. If one looks at the fortunes of autonomist parties in the four main autonomous community, one notices that in Catalonia Convergencia I Unio lost nearly half of its voters (from $29.28 \%$ to $17.44 \%$ ), while its more radical competitor Esquerra 
Republicana de Catalunya nearly doubled its score from $6.06 \%$ to $11.8 \%$. All in all, the overall nationalist vote in Catalunya declined considerably, especially the moderate section of the nationalist electorate. This shift in power relations between the moderate and radical independentist was already announced in the autonomous and statewide elections of 2003 and 2004, which led to the expulsion of the CiU from the Catalan government, and the formation of a coalition between the ERC, the Catalan Socialists and the Iniciativa Verds-Esquerra Alternativa.

In the Basque Country, the predominant nationalist force, the PNV presented a Basque cartel with the EA in 1999, obtaining 33.9\% of the Basque vote. In 2004, the PNV obtained by itself $35.3 \%$, while its left-wing competitor Eusko Alkartasuna obtained $7.8 \%$. Aralar, the new leftist-independist party, got $1.3 \%$. Most likely this increase in the nationalist vote is due to the disappearance of the political wing of the ETA, Euskal Herritarrok, that was shut down by law in 2003. The party appealed to its voters to abstain. Yet, as in 1999 the EB obtained 19.5\%, one must conclude that also in the Basque country the nationalist vote declined considerably, especially the most radical section. ${ }^{15}$ In Galicia, also the BNG lost almost half of its voters (21.98\% to $\left.12.32 \%\right)$. Finally, in Andalucia, Partido Andalucista lost more than half of its voters (from 6.64\% to 2.57\%), while its competitor, the Asamblea de Izquierdias - Partido Socialista de Andalucia, obtained only $0.26 \%$. In the other autonomies, the regionalist and autonomist parties tended to perform worse than in 1999, like in the Balearic Islands where the PSM went down from $9.2 \%$ to $3.6 \%$ and the Unio Mallorquina from $5.6 \%$ to $3.11 \%$. This heavy loss was only partially compensated by the score of the Catalan ERC (2.87\%), which did not compete on the Islands in 1999. On the Canaries, the Coalicion Canaria suffered a severe blow, losing about half of its voters (from $33.78 \%$ to $16.92 \%$ ). In the less autonomous regions on the mainland, the Partido Aragones lost heavily (from 9.27\% to $2.94 \%$ ) while the Chunta Aragonesista declined marginally (from 6.9\% to 6.1\%). In Valencia, the Unio Valenciana got wiped out (down from $4.0 \%$ to $0.49 \%$ ), while the Bloc Nacionalista Valencia declined from $2.4 \%$ to $1.1 \%$. In Navarra, the EA obtained $4.8 \%$, the PNV $2.1 \%$ while the Convergencia de Democratas de Navarra obtained $0.9 \%$. 
Finally in Asturias, la Rioja and Cantabria the nationalist formations together scored less than one percent of the regions' electorates.

In the new member states, regionalist parties did not fare well, and often did not even compete (as a single party) in the European elections, such as in Estonia, Lithuania, Czech Republic, ${ }^{16}$ Hungary, Malta, Cyprus, Slovenia and Poland. ${ }^{17}$ In Slovakia the Hungarian Federalist Party ran as a part of the Party of Hungarian Coalition (Magyar Koalíció Pártja) that is basically a Christian conservative party focusing on the Hungarians, and obtained 13.2\%, and two MEPs that joined the EPP. In Latvia, the ethnic Russian party For Human Rights in a Unified Latvia (FHRUL) obtained $10.7 \%$ and one MEP, and is associated to the EFA by individual membership of its MEP. Hence the new member states do not fit well the classic Rokkanite cleavage world, especially regarding the centre-periphery cleavage (Rokkan and Urwin, 1982; Seiler, 1995). Apart from some problems of protection of cross-border minorities (Hungarians in former territories of the Austro-Hungarian Empire, the Russian minorities in the Baltic states, and the territorially dispersed Roma) all current east-European countries are "nations with a state". Hence of the 112 seats that MEPs of enlargement countries occupy, only three can be considered as being captured by an autonomist party, and of these, only one joined the EFA. Thus enlargement seriously weakened the relative strength of the EFA vis-à-vis the other Europarties. In addition, as the EFA MEPs are usually elected on marginal seats (the last remaining seat to be attributed in the constituency), the current enlargement - that costs the 15 old member states 56 seats vis-à-vis the 1999-2004 parliament - further reduced the number of available seats in the constituencies in which the existing autonomist parties compete, and thus further eroded the parliamentary representation of the EFA (and also of the Greens).

Before 2004, most autonomist parties obtained generally better results at the European elections than at the parliamentary elections in their country, for a variety of reasons (more proportional electoral system, more opportunities to form electoral coalitions, lower turnout, anti-incumbent governing party vote, and lower campaign costs). De Winter's (2000) analysis ${ }^{18}$ shows that for the entire 1979-1999 period most autonomist 
parties did indeed obtain better results at European than at general elections. If we make a comparison between the regionalists' scores at the 2004 European elections and at the preceding general election, this pattern of superior European performances within the region's electorate is confirmed for SFP $(+1.1 \%)$, Plaid Cymru $(+3.1 \%)$, Vlaams Blok $(+4.4 \%)$, Lega Nord $(+1.1 \%$ at national level), Union Valdotaine $(+2.5 \%), \mathrm{BNG}(+0.9 \%)$, PNV $(+2.6 \%)$, Eusko Alkartasuna $(+1.3 \%)$. But in about as many cases the thesis must be rejected: for the SNP (-0.4\%), PDB (-2.4\%), CiU (-3.34\%), ERC (-4.1\%), CC (-7.4\%), CHA (-6.0\%) and PAR (-1.8\%), and the PA (-1.4\%). ${ }^{19}$ If we consider the twenty parties included in our table as "equal" and calculate the average of the scores they obtained in the 1999 and 2004 elections, the 2004 overall average of 14.5\% represents a drop of one third vis-à-vis the 1999 exemplary performance (19.3\%). Historically speaking, this is the lowest average since autonomist parties started to participate in the European elections (23\% in 1999, 20\% in 1984, $16 \%$ in 1989 and 18\% in 1994; see graph I). 